\title{
Crotoxin in humans: analysis of the effects on extraocular and facial muscles
}

\author{
Crotoxina em humanos: estudo da ação em músculos extraoculares e faciais
}

\author{
Geraldo de Barros Ribeiro ${ }^{1}$, Henderson Celestino de Almeida², David Toledo Velarde ${ }^{3}$
}

\begin{abstract}
Purpose: Crotoxin is the main neurotoxin of South American rattlesnake Crotalus durissus terrificus. The neurotoxic action is characterized by a presynaptic blockade The purpose of this research is to assess the ability of crotoxin to induce temporary paralysis of extraocular and facial muscles in humans.

Methods: Doses of crotoxin used ranged from 2 to 5 units $(U)$, each unit corresponding to one LD50. We first applied $2 \mathrm{U}$ of crotoxin in one of the extraocula muscles of 3 amaurotic individuals to be submitted to ocular evisceration. In the second stage, we applied crotoxin in 12 extraocular muscles of 9 patients with strabismic amblyopia. In the last stage, crotoxin was used in the treatment of blepharospasm in another 3 patients.

Results: No patient showed any systemic side effect or change in vision or any eye structure problem after the procedure. The only local side effects observed were slight conjunctival hyperemia, which recovered spontaneously. In 2 patients there was no change in ocular deviation after $2 \mathrm{U}$ crotoxin application. Limitation of the muscle action was observed in 8 of the 12 applications. The change in ocular deviation after application of $2 \mathrm{U}$ of crotoxin ( 9 injections) was in average 15.7 prism diopters (PD). When the dose was $4 \mathrm{U}$ ( 2 applications) the change was in average 37.5 PD and a single application of $5 \mathrm{U}$ produced a change of $16 \mathrm{PD}$ in ocular deviation. This effect lasted from 1 to 3 months. Two of the 3 patients with blepharospasm had the hemifacial spasm improved with crotoxin, which returned after 2 months.

Conclusions: This study provides data suggesting that crotoxin may be a useful new therapeutic option for the treatment of strabismus and blepharospasm. We expect that with further studies crotoxin could be an option for many other medical areas.
\end{abstract}

Keywords: Crotoxin/administration \& dosage; Crotoxin/therapeutic use; Strabismus/therapy; Oculomotor muscles; Blepharospasm/therapy

\section{RESUMO}

Objetivo: A crotoxina é a principal neurotoxina da cascavel sul-americana Crotalus durissus terrificus e sua ação neurotóxica caracteriza-se por um bloqueio pré-sináptico. O objetivo da pesquisa é avaliar a capacidade da crotoxina em induzir paralisia transitória de músculos extraoculares e faciais em seres humanos.

Métodos: As doses utilizadas de crotoxina foram de 2 a 5 unidades $(U)$, sendo que cada unidade correspondia a uma DL-50. Na primeira etapa, aplicou-se 2 U de crotoxina em músculos extraoculares de 3 indivíduos amauróticos, candidatos à evisceração. Na segunda etapa, realizaram-se 12 aplicações de crotoxina em músculos extraoculares de 9 indivíduos estrábicos e amblíopes. Na terceira e última etapa, utilizou-se a crotoxina para o tratamento do blefaroespasmo essencial em 3 indivíduos.

Resultados: Nenhum paciente demonstrou qualquer efeito sistêmico ou alteração da visão ou de qualquer estrutura ocular. O único efeito local adverso foi hiperemia conjuntival, que melhorou espontaneamente. Em 2 pacientes não houve alteração do desvio ocular após a aplicação de $2 U$ de crotoxina. Observou-se em 8 das 12 aplicações, limitação do movimento ocular no campo de ação do músculo aplicado. A diminuição do desvio ocular com $2 U$ crotoxina (9 aplicações) foi em média de 15,7 dioptrias prismáticas (DP); na dosagem de $4 U$ (2 aplicações) foi em média de 37,5 DP e na única aplicação de 5U, obteve-se redução de 16 DP no desvio ocular. A alteração do alinhamento ocular manteve-se por 1 a 3 meses. Dois dos 3 pacientes portadores de blefaroespasmo apresentaram melhora dos espasmos hemifacias, os quais voltaram após 2 meses.

Conclusões: Através dos resultados observados neste estudo, acreditamos que a crotoxina possa ser útil no tratamento do estrabismo e do blefaroespasmo. Novos estudos precisam ser realizados para confirmar a eficácia e a segurança da crotoxina como opção terapêutica para diversas áreas da medicina que atualmente utilizam a toxina botulínica.

Descritores: Crotoxina/administração \& dosagem; Crotoxina/usoterapêutico; Estrabismo/terapia; Músculos oculomotores; Blefarospasmo/terapia

\section{INTRODUCTION}

The term strabismus appears initially on the manuscripts of $\mathrm{Hi}$ pocrates (460 - 377 BC). The word has Greek origin, with strabós meaning misaligned or squinted. The treatment of the various types of strabismus has been improved all over the years. The importance of preventing amblyopia and the better understanding of the active and passive forces that coordinate ocular movements are unquestionable. On the XIX century, more precisely on October, $26^{\text {th }}, 1839$, Johann Friedrich Dieffenbach, a general surgeon from Berlin, corrected one case of strabismus doing miotomy in a medial rectus muscle. From this day on, a new era of strabology has begun (1). Graffe introduced the partial and controlled tenotomy, and also the advance of extraocular muscles on the treatment of strabismus ${ }^{(2)}$. Hummelsheim, in 1907, described a technique of transposition of the extraocular muscles to treat paralytic strabismus, experimentally caused in animals and, in 1908, used this technique on humans ${ }^{(3)}$. Several other techniques of extraocular muscle transpositions were subsequently described, such as O'Connor (1921) $)^{(4)}$, Jensen $(1964)^{(5)}$, Knapp (1969)(6), Almeida (1976)(7), Carlson and Jampolsky (1979)(8) and Brooks et al., (2000) $)^{(9)}$.

The first citation in literature about pharmacological treatment of strabismus was done in $1973^{(10)}$. The authors studied the effects of intramuscular injection of diisopropyl fluorophosphate (DFP), A-bungarotoxin (snake toxin), botulinum toxin type A and alcohol.
Submitted for publication: October 11, 2011

Accepted for publication: October 8, 2012

Study carried out at Strabismus Clinic of São Geraldo Hospital of Federal University of Minas Gerais - UFMG - Belo Horizonte (MG) - Brazil.

Physician, Preceptor of Strabismus Clinic, Universidade Federal de Minas Gerais - UFMG - Belo Horizonte (MG) - Brazil.

Chief Professor of Ophthalmology, Federal University of Minas Gerais - UFMG, School of Medicine, Belo Horizonte (MG) - Brazil.

${ }^{3}$ Biochemist, Hospital Foundation of Minas Gerais State - Fhemig, Belo Horizonte (MG) - Brazil.
Funding: No specific financial support was available for this study.

Disclosure of potential conflicts of interest: The authors Geraldo de Barros Ribeiro, Henderson Celestino de Almeida, and David Toledo Velarde have interests in the research Project. They are inventors of the UFMG (Universidade Federal de Minas Gerais) patent involving crotoxin use in humans.

Correspondence address: Geraldo de Barros Ribeiro. Av. Silviano Brandão, 1600 - Floresta - Belo Horizonte (MG) - 30015-015 - Brazil - E-mail: gbarrosribeiro@gmail.com 
They observed that DFP and alcohol were very toxic and did not show the desired effect of muscle paralysis. The bungarotoxin, a neurotoxin of a snake from India, showed no toxicity in the concentrations that were injected, and it caused a temporary paralysis of extraocular muscles in monkeys. However, this effect was too short, and did not reach the proposed objectives. The botulinum toxin type A caused a temporary paralysis of extraocular muscles in monkeys, with no side effects. After this animal experimentation, they concluded that botulinum toxin type A was appropriate for injection in humans, to treat strabismus ${ }^{(12)}$. Other therapeutic applications of botulinum toxin, in ophthalmology, were studied right after. The use of this drug in essential blepharospasm treatment is, nowadays, the treatment of choice $^{(12,13)}$.

Botulinum toxin is a neurotoxin, with molecular weight of $900 \mathrm{KDa}$. This complex has eight serotypes, classified from A to G, with similar structures and functions. All types are synthesized with one single branch of polypeptides, of approximately $150 \mathrm{KDa}$. After the separation of the toxin, to obtain only type $\mathrm{A}$, the $150 \mathrm{KDa}$ polypeptides branch transforms into a molecule with two branches, one with $100 \mathrm{KDa}$, and the other with $50 \mathrm{KDa}$. The heavy chain is responsible for the high affinity of the neurotoxin to the presynaptic termination, thus allowing its entrance into the cell. The light branch is responsible for the lesions of membrane proteins that do the binding of vesicles containing acetylcholine in the interior of the nerve terminal. These damaged proteins are called SNAP-25, and they have a molecular weight of $25 \mathrm{KDa}$. After the damage of these proteins, the acetylcholine release is impaired ${ }^{(14)}$. Other toxins that act in the neuromuscular joint could also be useful in the treatment for strabismus and other diseases in which botulinum toxin type A has been successfully used. The neurotoxin - crotoxin - due to its high toxicity could have a similar effect to botulinum toxin type A. Crotoxin is the main neurotoxin in the poison of South American rattlesnake, Crotalus durissus terrificus. This species is found in the Brazilian territory, and it is considered one of the most dangerous snakes of the occident, due to the high toxicity of its poison ${ }^{(15)}$.

The poison of the South American rattlesnake, usually, does not cause any local reaction but produces three main systemic alterations: neurotoxic, myotoxic and blood clotting. The neurotoxic activity is characterized by the blockade of neurotransmitter release of the peripheral neuron at the motor end-plate, causing muscular paralysis. The clinical profile is composed of discrete local manifestation and systemic intoxication that can be severe. Muscle paralysis caused by the neurotoxin effect of rattlesnake poison can produce acute breathing insufficiency, which can lead to death. The specific treatment is done with anti-crotalic serum, or with the specific portion of anti-ophidic serum ${ }^{(16)}$.

Crotoxin blocks the release of acetylcholine at the presynapsis. This blocking occurs in three stages. At the first stage acetylcholine release diminishes, possibly related to binding of the toxin to the receptor at the neural membrane. This stage lasts around five minutes. At the second stage, occurs an increase of neurotransmitter release, due to the increase of calcium concentration in peripheral motor neuron cytoplasm. This stage takes between ten to thirty minutes. At the third stage, occurs the progressive reduction until the complete blockade in acetylcholine release ${ }^{(17,18)}$.

Based on the crotoxin effect as a neuromuscular blocker, we initially studied its effect on inducing temporary muscle paralysis in animals. With the good results obtained, we have decided to analyze its effect in humans.

The objective of this study was to evaluate the efficacy of crotoxin to induce facial and extraocular muscle paralysis in human beings, analyzing also its duration and possible side effects.

\section{METHODS}

This study was carried out at the Strabismus Clinic of São Geraldo Hospital of Federal University of Minas Gerais (UFMG) - School of Me- dicine - Belo Horizonte (MG) - Brazil. It was approved by the Research Ethics Committee (COEP) of UFMG.

Crotoxin used in this study was obtained from Immunobiological Division of Ezequiel Dias Foundation (FUNED) of Belo Horizonte (MG) - Brazil.

\section{CROTOXIN PREPARATION}

The extraction of rattlesnake poison, the purification of crotoxin and the LD50 research were all done at FUNED.

\section{Determination of LD50}

The toxicity of this solution was determined through LD50 in mice with 18 to 22 grams, through intraperitoneal injection. Female and male mice were used in groups of eight animals per dose, with reading after 48 hours. We defined that one LD50 of crotoxin would correspond to one unit (U). Estimated LD50 for a $70 \mathrm{~kg}$ person would be equivalent to 3,500 LD50 obtained with mice.

The most frequently used botulinum toxin type A (BTX-A), is Botox ${ }^{\oplus}$, and one unit of it corresponds to 1 LD50. In treating strabismus, we usually use 5 to 10 units in each extraocular muscle. In blepharospasm are used 25 to 50 units, and in bigger muscles (e.g., lower limbs), $100 \mathrm{U}$ may be used.

\section{DEFINITION OF SUBJECTS FOR RESEARCH}

Gender, social class, and skin color have not influenced the selection of individuals for this research. All individuals were 18 years old or up. They fulfilled prerequisites and were invited to participate in the project and, those that accepted, signed a free informed consent, approved by the Research Ethics Committee/Investigational Review Board of the Federal University of Minas Gerais.

Individuals injected with crotoxin were followed-up with ophthalmological and clinical exams, in order to observe possible local and systemic side effects. On the first stage of the study, three individuals with amaurosis (blindness) in one eye, to be submitted to evisceration for ocular prosthesis, were invited to participate in this study (Group 1). All individuals were admitted to São Geraldo Hospital for follow-up. Two units of crotoxin (2 LD50) were injected in the medial rectus muscle of the atrophic eye. As there were no significant side effects, cross-eyed individuals were selected, with no restriction of eye movements (group 2), with low vision in one eye $(n=9)$ ). Crotoxin effects on extraocular muscles were evaluated through eye movements (version) and ocular alignment measured through corneal reflex (Krimsky's method). The injection of crotoxin was done using a sound eletromyograph of Allergan brand, model 90016 . The injection was done into the extraocular muscle, with a $37 \mathrm{~mm} \times 27 \mathrm{G}$ electrode needle, model 91079 (Allergan). Crotoxin concentration was of $2 \mathrm{U}$ in a $0.1 \mathrm{ml}$ solution.

On the third stage of this study, three individuals with essential blepharospasm were selected, (group 3). The effect of crotoxin was evaluated, observing the improvement of symptoms, and also the characteristic signs of the disease.

\section{RESULTS}

Group 1 - $2 \mathrm{U}$ of crotoxin were injected in the medial rectus muscle of the atrophic eye of three male individuals. It was observed that only one patient showed mild conjunctival hyperemia at the site of the injection, which improved spontaneously in two days. No systemic symptoms related to crotoxin application were observed.

Group 2 - We did 12 applications in 9 cross-eyed patients (Table 1), six were females. No systemic effects were observed, and there was no alteration of sight or eye structure. We only observed mild conjunctival hyperemia in one patient and complaints of pain or muscle pulling sensation at the site of the injection in three patients. No local or systemic medication was used after the injection of crotoxin. The 
side effects improved spontaneously in all cases. In 8 of 12 patients, it was observed a limitation in ocular movement in the field of action of the treated muscle, varying from -1 to -4 , in a scale from $-1=25 \%$ and $-4=100 \%$. In all cases there was progressive and total recovery of ocular movements after varying periods of time. The improvement of ocular deviation with $2 \mathrm{U}$ of crotoxin (nine injections) was in average 15.7 prism diopters (PD), but in two patients there was no change in deviation. With a dose of $4 \mathrm{U}$ (two injections) there was an average correction of 37.5 PD. In the single injection of $5 \mathrm{U}$ of crotoxin, we observed an improvement of only 16 PD in ocular deviation, probably due to extravasation of crotoxin during the injection. Ocular alignment alteration was maintained for up to three months. Examples: figures 1 to 4.

Group 3 - Crotoxin was injected into 3 female patients with essential blepharospasm. All patients have already been submitted to botulinum toxin injections. Two patients had improved of the hemifacial spasms, which returned intermittently after 2 months. One patient had no significant improvement after crotoxin injection. Two patients complained of discrete local pain, which improved spontaneously after two days.

\section{DISCUSSION}

In the first study about strabismus treatment with botulinum toxin type A (BTX-A), Scott ${ }^{12}$ did 67 injections into 19 patients. The initial doses of BTX-A, considered effective, were of $6.25 \times 10^{-5}$ and $3.12 \times 10^{-4}$ micrograms $(\mu \mathrm{g})$ in a $0.1 \mathrm{~mL}$ solution. This last dose was then repeated and increased according to the response obtained. LD50 of injected BTX-A was $4.3 \times 10^{-4}$. All injections with doses up to $6.25 \times 10^{-5}$ $\mu \mathrm{g}$ needed new injections or the treatment would be considered inadequate. When the dose was $3.12 \times 10^{-4} \mu \mathrm{g}$, there was a response considered adequate in four of the ten injections done. At doses of $1.56 \times 10^{-3} \mu \mathrm{g}$ (3.62 LD50), two of four injections were considered adequate. Maximum injected dose was $7.8 \times 10^{-3} \mu \mathrm{g}$, which corresponds to 18 LD50. In no patient the results lasted more than 60 days.

To ease the analysis and comparison, we describe our results in a similar way to the initial study of Scott about BTX-A ${ }^{(12)}$ (Tables 2 and 3 ).

Analyzing the results, we believe that the ideal dose of crotoxin to be injected into extraocular muscles is $5 \mathrm{U}$ diluted in $0.1 \mathrm{~mL}$ solution. In injections done with $4 \mathrm{U}$ in $0.2 \mathrm{~mL}$ and $5 \mathrm{U}$ in $0.25 \mathrm{~mL}$, the greater volume of solution increased the extravasation of the

Table 1. Study conducted with nine patients submitted to crotoxin injection (1U = 1 LD50)

\begin{tabular}{|c|c|c|c|c|c|c|c|}
\hline Patient & Age & Deviation (PD) & $\begin{array}{c}\text { Crotoxin } \\
\text { dose applied }\end{array}$ & $\begin{array}{l}\text { Improvement in } \\
\text { deviation (PD) }\end{array}$ & $\begin{array}{l}\text { Limitation of eye movement } \\
\text { in the field of action of the } \\
\text { injected muscle }\end{array}$ & Duration & Side effects \\
\hline 1 & 52 & LHypoT 35 & $2 U$ & 15 & $-2 /-4$ & 3 months & None \\
\hline 2 & 21 & ET 50 & $2 U$ & 20 & $-1 /-4$ & 1 month & None \\
\hline 3 & 37 & XT 20 & $2 U$ & Zero & None & - & $\begin{array}{l}\text { Discrete local pain } \\
\text { for three days }\end{array}$ \\
\hline 4 & 18 & ET 65 & $2 U$ & 20 & $-1 /-4$ & 1 month & $\begin{array}{l}\text { Local pull slightly sensation } \\
\text { on the site of the injection }\end{array}$ \\
\hline 5 & 35 & ET 45 & $2 U$ & 27 & $-1 /-4$ & 1 month & None \\
\hline 5 & 35 & ET 45 & $2 U$ & 25 & $-1 /-4$ & 1 month & None \\
\hline 6 & 43 & ET 95 & $2 \mathrm{U}$ & 15 & None & 1 month & None \\
\hline 7 & 19 & ET 10 & $2 \mathrm{U}$ & 20 & None & 2 months & None \\
\hline 7 & 19 & ET 10 & $4 U$ & 55 & $-4 /-4$ & 3 months & None \\
\hline 8 & 49 & ET 35 & $2 \mathrm{U}$ & Zero & None & - & $\begin{array}{c}\text { Local discrete conjunctival } \\
\text { hyperemia }\end{array}$ \\
\hline 8 & 49 & ET 35 & $4 U$ & 20 & $-1 /-4$ & 2 months & $\begin{array}{l}\text { Local pull slightly sensation } \\
\text { for two days }\end{array}$ \\
\hline 9 & 44 & ET 20 & $5 U$ & 16 & $-1 /-4$ & 3 months & None \\
\hline
\end{tabular}

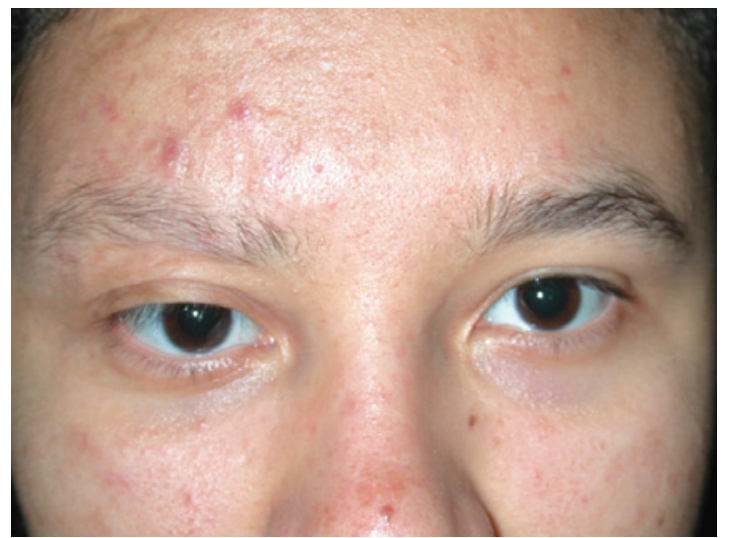

Figure 1. Female patient, 19 years old with 10 PD of esotropia, before crotoxin injection (patient \# 7).

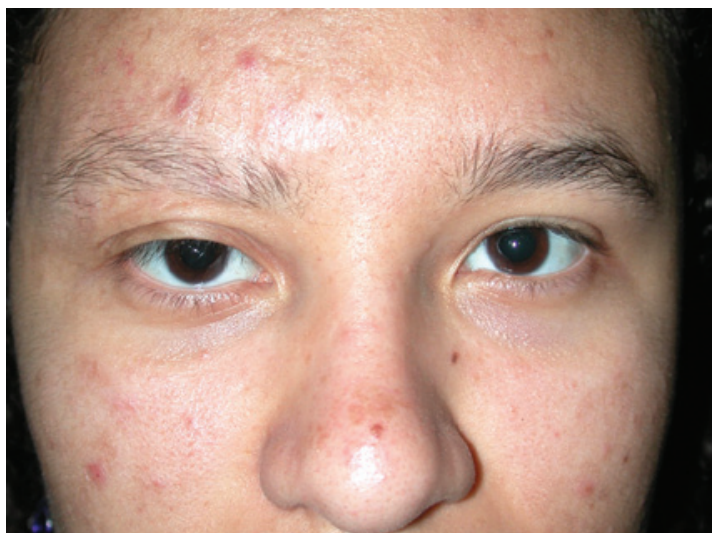

Figure 2. Same patient, with $10 \mathrm{PD}$ of exotropia, after the application of $2 \mathrm{U}$ crotoxin in the right medial rectus muscle. 


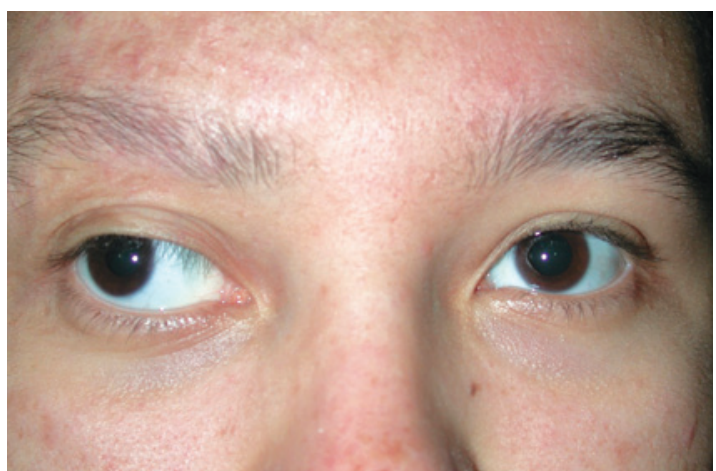

Figure 3. Same patient, after injection of $4 \mathrm{U}$ crotoxin in the right medial rectus muscle (RMR) ( $2^{\text {nd }}$ injection). Large-angle exotropia.

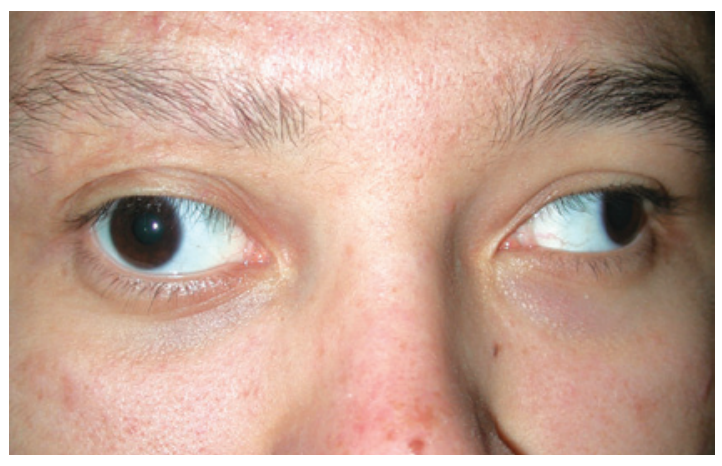

Figure 4. Same patient, with limitation of adduction RMR (-4/-4). drug, diminishing the desired effects, and increasing the possibility of complications.

An analysis of the current knowledge about the effects of botulinum toxin in many types of strabismus is necessary, because crotoxin would be indicated in the same cases.

Application of BTX-A into extraocular muscles is usually done through transconjunctival injection at the physician's office. BTX-A is mainly indicated for treatment of horizontal strabismus (esotropia more than exotropia), but particularly in cases of sixth nerve paralysis. It can also be used for cases of third and fourth nerves paralysis, in vertical deviations and thyroid orbitopathy ${ }^{(19)}$.

Final success in injection of BTX-A is, most of the times, preceded by a hypercorrection, associated with a movement limitation on the field of action of the injected muscle ${ }^{(20)}$. In our study 8 of 12 crotoxin applications caused reduction of rotation into field of muscle injected.

The use of BTX-A for treatment of small and medium angle strabismus was effective in a study conducted with 97 patients, with injection into one or both eyes. The indexes of therapeutic success, with deviation lower than 10 PD after three months of follow-up were: $57.1 \%$ (unilateral BTX-A injections) and $68.4 \%$ (bilateral BTX-A injections) and $72.4 \%$ (surgery). Differences were not statistically significant among the percentages of correction of ocular deviation and the index of therapeutic success among the three groups studied ${ }^{(14)}$.

The injection of BTX-A without using an eletromyograph (EMG) done in 40 children with different types of convergent strabismus has shown to be effective, with an index of complications comparable to those procedures done with EMG orientation. The use of forceps, specially developed for botulinum application into extraocular muscles has also shown to be effective as an alternative to the use of $E M G^{(21)}$. The use of BTX-A for treating convergent strabismus in patients with brain paralysis has shown to be effective with a single injection for $47.1 \%$ of 17 patients studied. Side effects were: sub-

Table 2. Study on the effects of BTX-A in extraocular muscles (Scott, 1980)

\begin{tabular}{|c|c|c|c|c|c|c|c|c|c|c|}
\hline Patient & $\begin{array}{c}\text { Age } \\
\text { (years) }\end{array}$ & Condition & $1 \times 10^{-7} \mu \mathrm{g}$ & $5 \times 10^{-7} \mu g$ & $2.5 \times 10^{-6} \mu \mathrm{g}$ & $1.25 \times 10^{-6} \mu \mathrm{g}$ & $6.25 \times 10^{-5} \mu \mathrm{g}$ & $3.12 \times 10^{-4} \mu \mathrm{g}$ & $1.56 \times 10^{-3} \mu \mathrm{g}$ & $7.8 \times 10^{-3} \mu \mathrm{g}$ \\
\hline 1 & 26 & 20 LXT & None & None & & & & & & \\
\hline 2 & 75 & 12 RET & None & None & & & & & & \\
\hline 3 & 26 & $\begin{array}{c}35 \text { RET } \\
\text { Sixth nerve paralysis }\end{array}$ & None & None & None & None & Mild & Moderate & Marked & \\
\hline 4 & 30 & $20 L X T$ & & None & None & None & Mild & Moderate & Marked & \\
\hline 5 & 43 & 30 LXT & & None & None & None & Mild & Moderate & Marked & Marked \\
\hline 6 & 24 & $45 \mathrm{LXT}$ & & & None & None & Mild & Moderate & Marked & \\
\hline 7 & 24 & $16 \mathrm{RXT}$ & & & None & None & Mild & Moderate & & \\
\hline 8 & 41 & 40 LXT & & & & None & & & & \\
\hline 9 & 70 & Lid retraction & & & & & Mild & Moderate & Moderate & \\
\hline 10 & 27 & $6 \mathrm{LHT}$ & & & & None & Mild & & & \\
\hline 11 & 38 & 20 LET & & & & None & Mild & $\begin{array}{l}\text { Moderate } \\
\text { Moderate } \\
\text { Marked }\end{array}$ & & \\
\hline 12 & 43 & 16 RET & & & & & & $\begin{array}{c}\text { Mild } \\
\text { Moderate }\end{array}$ & & \\
\hline 13 & 48 & ET RE 25 & & & & & & Marked & & \\
\hline 14 & 33 & $40 \mathrm{LXT}$ & & & & & & & & \\
\hline 15 & 39 & $2 \mathrm{EP}$ & & & & & $\begin{array}{l}\text { Mild } \\
\text { Mild }\end{array}$ & Moderate & & \\
\hline 16 & 33 & $6 \mathrm{RXT}$ & & & & & Mild & Moderate & & \\
\hline 17 & 59 & $\begin{array}{c}60 \mathrm{ET} \\
\text { Bilateral total } \\
\text { sixth nerve paralysis }\end{array}$ & & & & & Moderate & Moderate & & \\
\hline 18 & 19 & $25 \mathrm{RXT}$ & & & & & & Moderate & & \\
\hline
\end{tabular}


Table 3. Results classification on the study about the effects of BTX-A in extraocular muscle (Scott, 1980) ${ }^{(12)}$

\begin{tabular}{|c|c|c|c|c|}
\hline & Mild & Moderate & Marked & Extended \\
\hline Alignment in primary position (change in prism diopters) & to $10 \mathrm{PD}$ & to $20 \mathrm{PD}$ & to $30 \mathrm{PD}$ & Overcorrection beyond 60 days \\
\hline Rotational amplitude (reduction of basal amplitude) & $-1(0-20 \%)$ & $-2,-3(20-50 \%)$ & $-3,-4(50-100 \%)$ & Other muscles involved over 7 days \\
\hline $\begin{array}{l}\text { Velocity (saccades into field of muscle) } \\
\text { (\% of reduction) }\end{array}$ & to $20 \%$ & $20-50 \%$ & $50 \%$ & Decrease in ductions other than into full \\
\hline $\begin{array}{l}\text { Isometric force (from opposite gaze into field of muscle) } \\
\text { (\% of reduction) }\end{array}$ & to $20 \%$ & $20-50 \%$ & $50-100 \%$ & Reduction other muscles over 7 days \\
\hline Durations of effects & to 7 days & to 30 days & to 60 days & Not applicable \\
\hline
\end{tabular}

conjunctival hemorrhage, transitory vertical deviation and transitory blepharoptosis(22).

In cases of sixth nerve paralysis, it must be considered if it is a recent case (less than 6 months), or chronic case (more than 6 months) and whether the involvement is total (paralysis) or partial (paresis). Researchers found good results in treatment of acute sixth nerve paralysis, believing that by stopping or avoiding medial rectus muscle contracture, there would be a better recovery ${ }^{(23)}$. However, some studies have shown that the results in spontaneous recovery of sixth nerve palsy and in patients treated with BTX-A were not statistically significant. With these results, BTX-A success for treating sixth nerve paralysis must be interpreted with caution ${ }^{(24)}$. However, we believe that botulinum toxin must be applied to medial rectus muscle of every patient with recent paralysis of abducens nerve, particularly if it is of traumatic nature, to avoid contracture of the antagonist muscle and ease the surgical procedure, if it becomes necessary in the future.

The injection of BTX-A to treat strabismus is an adequate option to many patients that do not want to be submitted to additional surgery. The most common complication of BTX-A in treatment of strabismus is ptosis, probably due to spread of the toxin to orbital tissues. Asking the patient to stay seated right after the injection can diminish this side effect. A vertical deviation after the injection of BTX-A into horizontal muscles can also occur ${ }^{(25)}$. An inadvertent intraocular injection of BTX-A was reported and the patient had retinal detachment, treated with laser photocoagulation. Initially there was some loss of vision; however, after 2 days it returned to $6 / 6$, remaining stable for 5 years. This occurrence supports studies with animals indicating that the injection of BTX-A into the vitreous does not damage intraocular tissues ${ }^{(26)}$.

BTX-A has been used to treat many types of strabismus. Well conducted prospective studies are necessary to define in which types of strabismus BTX-A can be used to achieve better results than those of traditional surgery.

New studies must be done in order to increase knowledge on the efficacy and safety of crotoxin in humans.

\section{CONCLUSIONS}

As our results were similar to Scott's initial study, and as we did not observe any significant side effects, we believe crotoxin can be a new therapeutic option to many areas of medicine which currently are using botulinum toxin.

\section{REFERENCES}

1. Dieffenbach JB. Uber Die Heilungdes Angeborenem Schielens Mittels Durchsneidung des Innereren Geraden Augenmuskels. Medicinische Zei Tung Von Dem Verein Für Heilkunde. In Preussen. 1839;8:27-8.

2. Von Noorden GK. The history of strabismology. Belgium: J.P. Wayenborgh; 2002

3. Hummelsheim E. Ueber Sehnentransplantation am Auge. Ber Dtsch Ophthalmol. 1907;34:248.
4. O'Connor R. Transplantation of ocular muscles. Am J Ophthalmol. 1921:4:839-45.

5. Jensen CDF. Rectus muscle union: a new operation for paralysis of the rectus muscles. Trans Pac Coast Otoophthalmol Soc Annu Meet. 1964:45:359-87.

6. Knapp, P. The surgical treatment of double elevator paralysis. Trans Am Ophthalmol Soc. 1969;67:304-20.

7. Almeida, HC. Paralisia do nervo oculomotor: transplante do oblíquo superior. Rev Latino-Am Estrab. 1976:1:62-7.

8. Carlson MR, Jampolsky A. An adjustable transposition procedure for abduction deficiences. Am J Ophthalmol. 1979;87:382-7.

9. Brooks SE, Olitsky SE, de Ribeiro GB. Augmented Hummelsheim procedure for paralytic strabismus. J Pediatr Ophthalmol Strabismus. 2000;37(4):189-95.

10. Weidlich R. [The contribution of Alfred K. Graefe to surgical treatment of paretic squint in the second half of the 19th century]. Klin Monbl Augenheilkd. 1996;208(1):66-7. German.

11. Scott AB, Rosembaum A, Collins CC. Pharmacologic weakening of extraocular muscles. Invest Ophthalmol Vis Sci. 1973:12:924-7.

12. Scott $A B$. Botulinum toxin injection into extraocular muscles as an alternative to strabismus surgery. Ophthalmolology. 1980;87(10):1044-9.

13. Frueh BR, Felt DP, Wojno TH, Musch DC. Treatment of blepharospasm with botulinum toxin: A preliminar report. Arch Ophthalmol. 1984;102(10):1464-8

14. Scott $A B$, Kraft SP. Botulinum toxin injection in the management of lateral rectus paresis. Ophthalmology. 1985;92(5):676-83.

15. Villas Boas ML, Almeida HC. Comparação entre cirurgia e aplicações unilaterais e bilaterais de toxina botulínica para o tratamento dos estrabismos. Arq Bras Oftalmol [Internet]. 2001 [citado 2011 Jan 21];64(5):405-10. Disponível em: http://www.scielo. br/pdf/abo/v64n5/8358.pdf

16. Klauber LM. Rattlesnakes, their habits, lifes histories and influence on mankind. Berkley: California. University of California Press; 1956.

17. Campos AC. Efeito da crotoxina na fosforilação de proteínas da fração sinaptosomal de córtex de rato [tese]. Belo Horizonte: Universidade Federal de Minas Gerais; 2000.

18. Chang CC, Lee CY. Isolation of neurotoxins from the venon of Bungarus multicinctus and their modes of neuromuscular blocking action. Arch Int Pharmacodyn Ther. 1963:144:241-57.

19. Hawgood B, Bon C. Snake venom presynaptic toxins. In: Tu A, Fu T, Tu T, editors. Handbook of natural toxins: reptile venoms and toxins. New York: Marcel Dekker; 1990. p.5-32.

20. Wattiez R, Casanova FH, Cunha RN, Mendonça TS. Correção de estrabismo paralítico por injeção de toxina botulínica. Arq Bras Oftalmol [Internet]. 2000 [citado 2009 Jul 21];63(1): 71-7. Disponível em: http://www.scielo.br/pdf/abo/v63n1/13609.pdf

21. Gomez de Liano R, Mompean B, Gómez de Liaño P. Tratamiento del estrabismo infantil mediante toxina botulinica. Acta Estrabologica. 1993:3-8.

22. Mendonça TF, Cronemberger MF, Lopes MC, Nakanami CR, Bicas HE. Comparação entre os métodos de injeção de toxina botulínica em músculo ocular externo com o uso do eletromiógrafo e com o uso da pinça de Mendonça. Arq Bras Oftalmol [Internet]. 2005 [citado 2009 Mar 19];68(2):245-9. Disponível em: http://www.scielo. br/pdf/abo/v68n2/23890.pdf

23. Cronemberger MF, Mendonça TS, Bicas HE. Toxina botulínica no tratamento de estrabismo horizontal em crianças com paralisia cerebral. Arq Bras Oftalmol [Internet]. 2006 [citado 2009 Ago 25];69(4):523-9. Disponível em: http://www.scielo.br/pdf/abo/ v69n4/31574.pdf

24. Metz HS, Dickey CF. Treatment of unilateral acute sixth nerve palsy with botulinum toxin. Am J Ophthalmol. 1991:112(4):381-4.

25. Holmes JM, Beck RW, Kip KE, Droste PJ, Leske DA. Botulinum toxin treatment versus conservative management in acute traumatic sixth nerve palsy or paresis. JAAPOS. 2000;4(3):145-9.

26. Stavis M. Ptosis: a preventable side effect following botulinum injection for strabismus. Am Orthoptic J. 1985:35:53-8.

27. Liu M, Lee HC, Hertle RW, Ho AC. Retinal detachment from inadvertent intraocular injection of botulinum toxin A. Am J Ophthalmol. 2004;137(1):201-2. 